\title{
Comparison of Acute Cardiovascular Responses during a Rowing Test in Laboratory and Field Conditions
}

\author{
Nikolaos Koutlianos, Nikolaos Panolias, Milena Tomović, Serafeim Alexiou \\ Sport Medicine Laboratory, School of Physical Education and Sports Science, \\ Aristotle University of Thessaloniki, Greece
}

SUMMARY

This study compares the acute cardiovascular responses of rowing athletes during a rowing test in laboratory and field conditions in order to identify possible differences between the two types of the rowing tests.

Six male rowers completed the rowing tests, using the Concept 2 rowing paddle at the laboratory and a skiff in the water. Heart rate, blood pressure (systolic and diastolic) and oxygen saturation (\% SpO2) were measured in both tests.

Data analysis showed no significant differences regarding the heart rate $(p>0.05)$, systolic blood pressure $(p>0.05)$ and the oxygen saturation rate $(p>0.05)$ between the laboratory and field trials, while a similar evolution of these parameter values was recorded at all times when the measurements were taken. Only at diastolic pressure values, there were statistically significant differences in the measurements taken immediately post the rowing test and the values obtained up to the $7^{\text {th }}$ minute of the recovery.

Overall, there were only slight fluctuations in the cardiovascular responses of the rowing athletes, between the laboratory test and the field test, and the laboratory test may be quite reliable for the performance assessment of the rowers. However, field trials are reported to have the advantage of offering greater validity and specificity because they better simulate actual competition events.

Key words: rowing, ergometry, field performance tests, cardiovascular responses to exercise

Corresponding author:

Nikolaos Koutlianos

e-mail: koutlian@phed.auth.gr 


\section{INTRODUCTION}

Athletes' performance evaluation is the first, integral and probably the most important part when training program plan is created. Testing procedures used for sport specific performance evaluation are various and very often mimic the sport discipline itself. Furthermore, performance evaluation process depends on several other factors such as predominant load type, age, sex, environmental conditions, sport equipment etc. and can be laboratory and fieldbased $(1-3)$. Laboratory tests are conducted in controlled environment and use standard protocols, equipment and skilled personnel (4), thus providing sufficient reliability and accuracy in the results of the measured parameters (5). Field trials, on the other hand, are conducted outside the laboratory environment offering greater validity and specificity because they better simulate actual competition events $(4,5)$.

Rowing is a high intensity sport's discipline that includes both aerobic and anaerobic power with a ratio of approximately $70-30 \%$, respectively (2). The same ratio shows higher aerobic contribution in on-water compared to ergometer rowing (6). Additionally, kinematic analyses suggest that the dynamics of movement in the ergometer is different from that adopted in the water $(7,8)$. Available research shows that handle force, acceleration profiles, stroke timing and consistency also differ $(9,10)$. On the other hand, on-water rowing tests' accuracy and reliability depend greatly on the environmental conditions and its variant nature. Wind velocity, wind direction and water conditions are changing during and between tests which makes the work load standardization very difficult and therefore on-water rowing performance evaluation as well $(11,12)$. The abovementioned raises concerns about the optimal possible simulation of the rowing performance in and out of water.

According to the mentioned relative differences between these two rowing modes and the subsequent changes in physiological and cardiovascular responses, it is hypothesized that laboratory ergometer rowing tests may not be adequate for outdoor training prescription. Research in this area is quite limited to date (13), thus the purpose of this study is to compare the acute cardiovascular responses of rowing athletes, and in particularly heart rate, blood pressure and oxygen saturation during rowing test in laboratory and field (on-water) conditions.

\section{PARTICIPANTS AND METHODS}

The study involved six male rowers. The eligibility criteria for the survey was that participants were men aged $18-23$ and had at least two years of training experience in rowing. Athletes were excluded from the survey if they had a serious health problem or an injury during the last 12 months. All measurements were conducted during the competitive season.

The rowers who took part in the study were submitted to two $2000 \mathrm{~m}$ rowing tests i.e. one in the lab and one in the water. In the laboratory environment, the test was carried out on a rowing ergometer (Concept2) (constant temperature $19^{\circ} \mathrm{C}$ ), while the field test in the water was executed with a skiff-type boat. In trials, a common warm-up (4000 m with 3 15-paddles jumps), a common start (25 paddles), and the same rhythm were maintained throughout the test (30 - 32 paddles per minute), and finally a climb ( 25 paddles) before finishing. The parameters evaluated in the tests were heart rate, blood pressure (systolic and diastolic), and oxygen saturation ( $\mathrm{SpO} 2 \%)$.

The measurements for all three parameters took place before the tests started and 10 minutes after the pre-set warm-up was done both in the field and in the laboratory. During the tests, cardiac frequency was continuously recorded. At the end of the tests, all three variables were measured immediately after the finish of the $2000 \mathrm{~m}$ effort, at the $3^{\text {rd }}, 5^{\text {th }}$ and $7^{\text {th }}$ min of recovery.

Polar M400 HR (Polar ElectroInc., Kempele, Finland) waterproof watch with heart rate monitor was used to monitor heart rate and a medical blood pressure gauge (Microlife model: BP3BE0, Friborg, Switzerland) was used to monitor blood pressure. The oxygen saturation rate was measured with a medical oximeter (Sanitas tape: SPO2\%, Utterweiler Germany).

Statistical analysis of the results was carried out using descriptive statistics (mean values and standard deviations) and a variance analysis of repeated measurements with one factor (type of the test, measurements) was used to check whether there was a significant influence of the group on the evolution of the heart rate. The significance level was set at $\mathrm{p}<0.05$. 


\section{RESULTS}

The mean age of the rowers was 21.0 years and they weighed $84.5 \mathrm{~kg}$ (range $72-96 \mathrm{~kg}$ ) and had an average height of $184.5 \mathrm{~cm}$ (range $178-189 \mathrm{~cm}$ ), with an average training experience of 10.17 years, (range 6 - 17 years) and the average duration of their training sessions was 2.92 hours ( 2 - 4 hours) (Table 1 ).
In both trials, the heart rate rhythm was similar over time $(\mathrm{F}=0.218, \mathrm{p}=0.927>0.05)$, where it significantly increased immediately after the end of the test, and from that point up to 7 minutes after the end of the test was significantly reduced in both tests. The heart rate was significantly increased by $25.56 \%$ (rowing ergometer) and by $22.82 \%$ (in the rowing boat) 7 minutes after the test compared to

Table 1. Descriptive features of the participants

\begin{tabular}{l|c|c|c|c}
\hline \hline & $\begin{array}{c}\text { Mean } \\
(\mathrm{M})\end{array}$ & $\begin{array}{c}\text { Standard Deviation } \\
(\mathrm{SD})\end{array}$ & Minimum & Maximum \\
\hline Age (yrs) & 21.00 & 2.00 & 18.00 & 23.00 \\
\hline Training experience (yrs) & 10.17 & 3.92 & 6.00 & 17.00 \\
\hline Training session duration (hrs) & 2.92 & 0.66 & 2.00 & 4.00 \\
\hline Training frequency/ week (days) & 6.17 & 0.98 & 5.00 & 7.00 \\
\hline Height $(\mathrm{cm})$ & 184.50 & 3.67 & 178.00 & 189.00 \\
\hline Weight $(\mathrm{kg})$ & 84.50 & 8.38 & 72.00 & 96.00 \\
\hline \hline
\end{tabular}

Table 2. Results of heart rate in both tests

\begin{tabular}{|c|c|c|c|c|}
\hline \multirow{2}{*}{ Heart Rate (Beats /min) } & \multicolumn{2}{|c|}{ Concept2 } & \multicolumn{2}{|c|}{ Skiff in water } \\
\hline & Mean & SD & Mean & SD \\
\hline Rest $^{\mathrm{NS}}$ & 88.67 & 7.34 & 89.83 & 7.28 \\
\hline End of test ${ }^{N S}$ & 190.50 & 3.73 & 188.00 & 6.69 \\
\hline Post 3 mins $^{N S}$ & 139.50 & 13.66 & 141.33 & 7.58 \\
\hline Post 5 mins $^{\mathrm{NS}}$ & 126.33 & 15.40 & 125.67 & 12.79 \\
\hline Post 7 mins $^{N S}$ & 111.33 & 6.80 & 110.33 & 5.75 \\
\hline $\begin{array}{c}\text { Variation from rest to post } \\
7 \text { mins of recovery } \\
\end{array}$ & \multicolumn{2}{|c|}{$25.56 \%$} & \multicolumn{2}{|c|}{$22.82 \%$} \\
\hline
\end{tabular}

Ns: Non-significant Concept2 vs Skiff in water

baseline values at rest (Table 2, Figure 1).

Figures 2 and 3 show the heart rate responses as they were monitored during the two rowing efforts as well as the actual exercise time.

Systolic $(\mathrm{F}=0.322, \mathrm{p}=0.583)$ and diastolic blood pressure $(\mathrm{F}=0.766, \mathrm{p}=0.554)$ of the rowers also had similar evolution over time for both tests. Both systolic and diastolic blood pressure increased significantly immediately after the end of the test, and from that point up to 7 minutes post the termination of the test, systolic pressure decreased significantly for both tests, while for diastolic pressure there was a significant variation in both tests. In more detail, systolic pressure increased by $2.63 \%$ in the lab test, and decreased by $2.86 \%$ in the skiff test at the $7^{\text {th }}$ minute of recovery compared to resting values (Table 3, Figure 4). The diastolic pressure dropped by $8.45 \%$ in the rowing ergometric test and increased by $5.49 \%$ in the boat test in water at the $7^{\text {th }}$ minute of recovery compared to rest (Table 4, Figure 5).

In both trials, $\mathrm{SPO} 2$ of the rowers had a similar evolution over time $(F=0.622, p=0.649>0.05)$, as it significantly decreased immediately after the test, and from that point up to 5 minutes after the end of the test was significantly reduced. A significant increase in $\mathrm{SPO} 2$ was observed in both tests between the values at the finish line and the $7^{\text {th }}$ min of recovery (Table 5, Figure 6). 


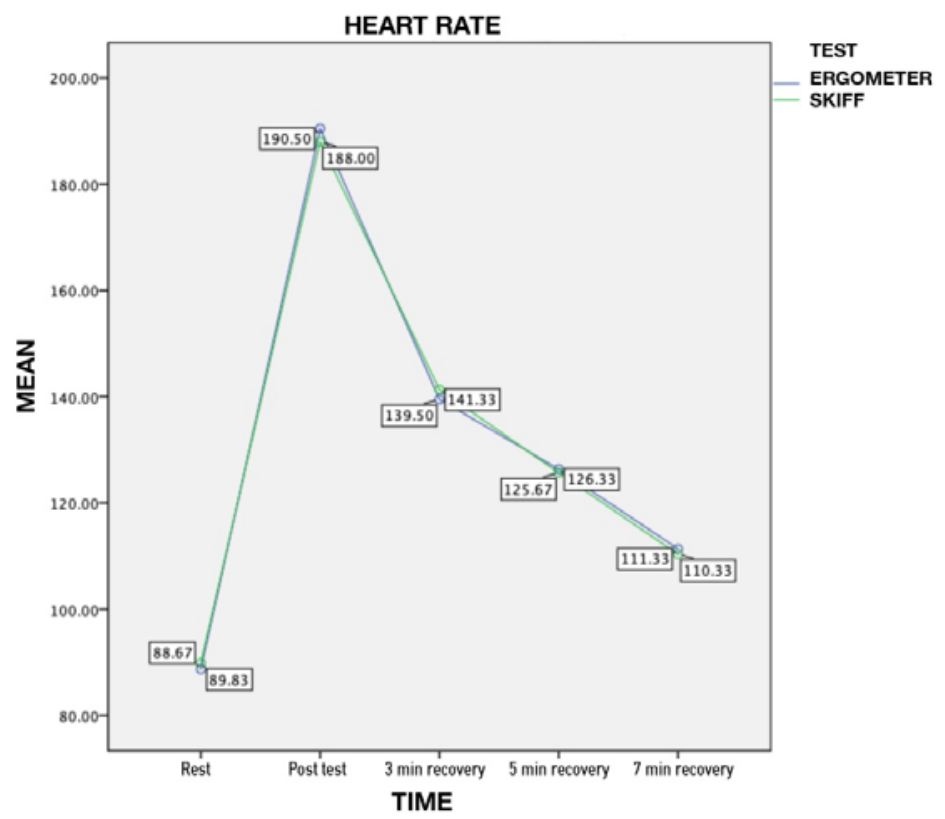

Figure 1. Diagram of heart rate (beats/min) according to the time and the ergometric test

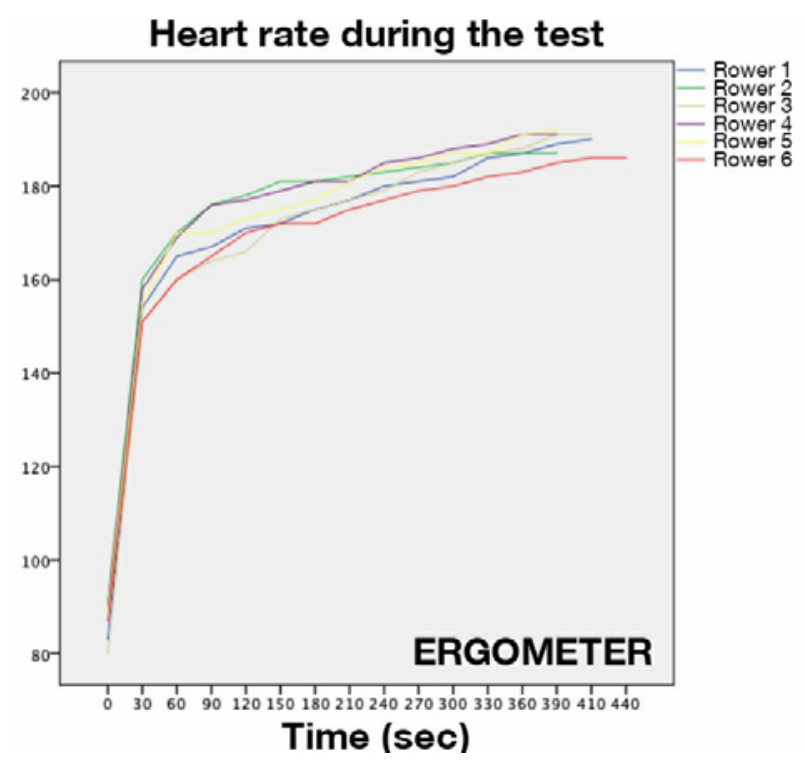

Figure 2. Diagram of heart rate (beats/min) response during the lab rowing test

Table 3. Results of systolic blood pressure in both tests

\begin{tabular}{c|c|c|c|c}
\hline \hline \multirow{2}{*}{$\begin{array}{c}\text { Systolic pressure } \\
(\mathrm{mmHg})\end{array}$} & \multicolumn{2}{|c|}{ Concept2 } & \multicolumn{2}{c}{ Skiff in water } \\
\cline { 2 - 5 } & Mean & SD & Mean & SD \\
\hline Rest $^{\mathrm{NS}}$ & 133.33 & 12.60 & 128.50 & 9.31 \\
\hline End of test & 176.50 & 43.29 & 165.83 & 15.20 \\
\hline Post 3 mins & 171.50 & 18.23 & 154.67 & 19.01 \\
\hline Post 5 mins & 151.83 & 24.81 & 139.83 & 10.44 \\
\hline Post 7 mins & 136.83 & 12.97 & 124.83 & 9.45 \\
\hline $\begin{array}{l}\text { Variation } \% \text { from rest to } \\
\text { post 7 mins of recovery }\end{array}$ & \multicolumn{2}{|c}{$2.63 \%$} & $-2.86 \%$ \\
\hline \hline
\end{tabular}

NS:Non-significant Concept2 vs Skiff in water 


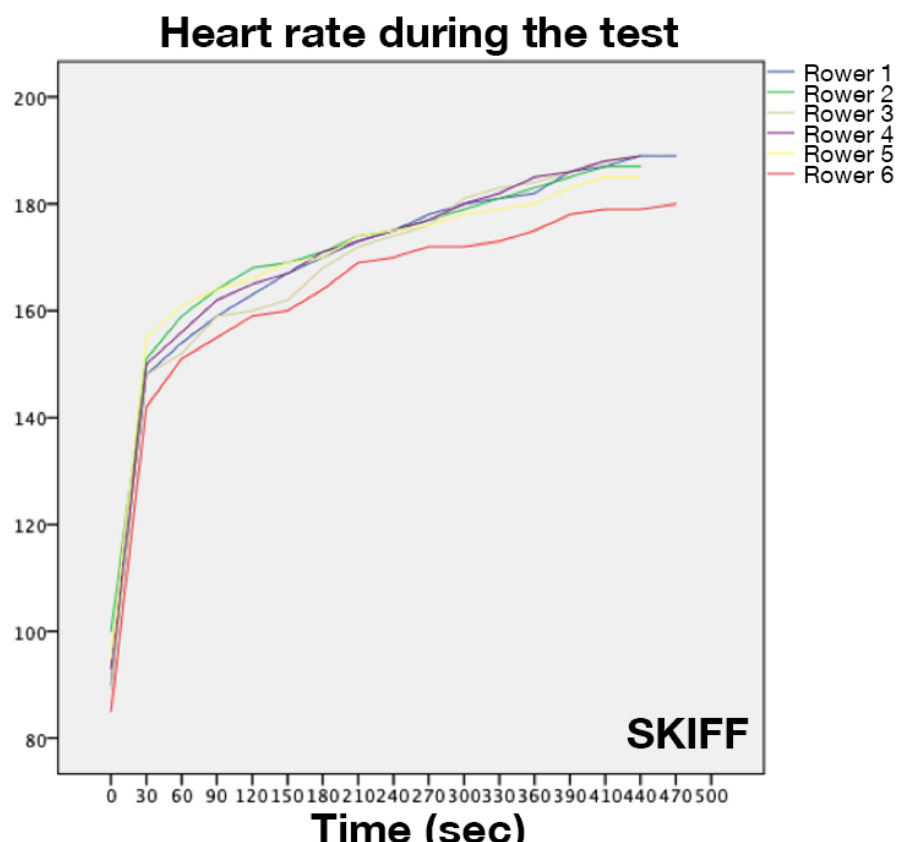

Figure 3. Diagram of heart rate (beats/min) response during the field rowing test

Table 4. Results of diastolic blood pressure in both tests

\begin{tabular}{c|c|c|c|c}
\hline \hline \multirow{2}{*}{$\begin{array}{c}\text { Diastolic pressure } \\
(\mathrm{mmHg})\end{array}$} & Concept2 & \multicolumn{3}{|c}{ Skiff in water } \\
\cline { 2 - 5 } & Mean & SD & Mean & SD \\
\hline Rest $^{\mathrm{NS}}$ & 80.83 & 11.27 & 82.00 & 5.10 \\
\hline End of test & \\
\hline Post 3 mins $^{\mathrm{S}}$ & 83.83 & 13.86 & 92.00 & 22.65 \\
\hline Post 5 mins ${ }^{\mathrm{NS}}$ & 99.00 & 22.97 & 89.83 & 24.59 \\
\hline Post 7 mins & 77.50 & 12.28 & 80.67 & 10.63 \\
\hline $\begin{array}{l}\text { Variation from rest to } \\
\text { post 7 mins of recovery }\end{array}$ & 74.00 & 12.07 & 86.50 & 8.22 \\
\hline \hline
\end{tabular}

Ns:Non-significant Concept2 vs Skiff in water

S:p $<0.05$ Concept 2 vs Skiff in water

Table 5. Results of SPO2in both tests

\begin{tabular}{|c|c|c|c|c|}
\hline \multirow{2}{*}{$\mathrm{SPO}_{2}$} & \multicolumn{2}{|c|}{ Concept2 } & \multicolumn{2}{|c|}{ Skiff in water } \\
\hline & Mean & $\mathrm{SD}$ & Mean & SD \\
\hline Before $^{N S}$ & 98.83 & .41 & 98.33 & .82 \\
\hline End of test ${ }^{\mathrm{NS}}$ & 96.33 & 4.68 & 97.50 & 1.52 \\
\hline Post 3 mins ${ }^{N S}$ & 96.50 & 2.74 & 96.33 & 2.34 \\
\hline Post 5 mins $^{\mathrm{NS}}$ & 96.50 & 2.81 & 97.67 & .82 \\
\hline Post 7 mins $^{\mathrm{NS}}$ & 97.67 & .52 & 98.17 & 1.17 \\
\hline $\begin{array}{l}\text { Variation from rest to post } \\
7 \text { mins of recovery }\end{array}$ & \multicolumn{2}{|c|}{$-1.17 \%$} & \multicolumn{2}{|c|}{-0.16} \\
\hline
\end{tabular}

NS:Non-significant difference Concept2 vs Skiff in water 


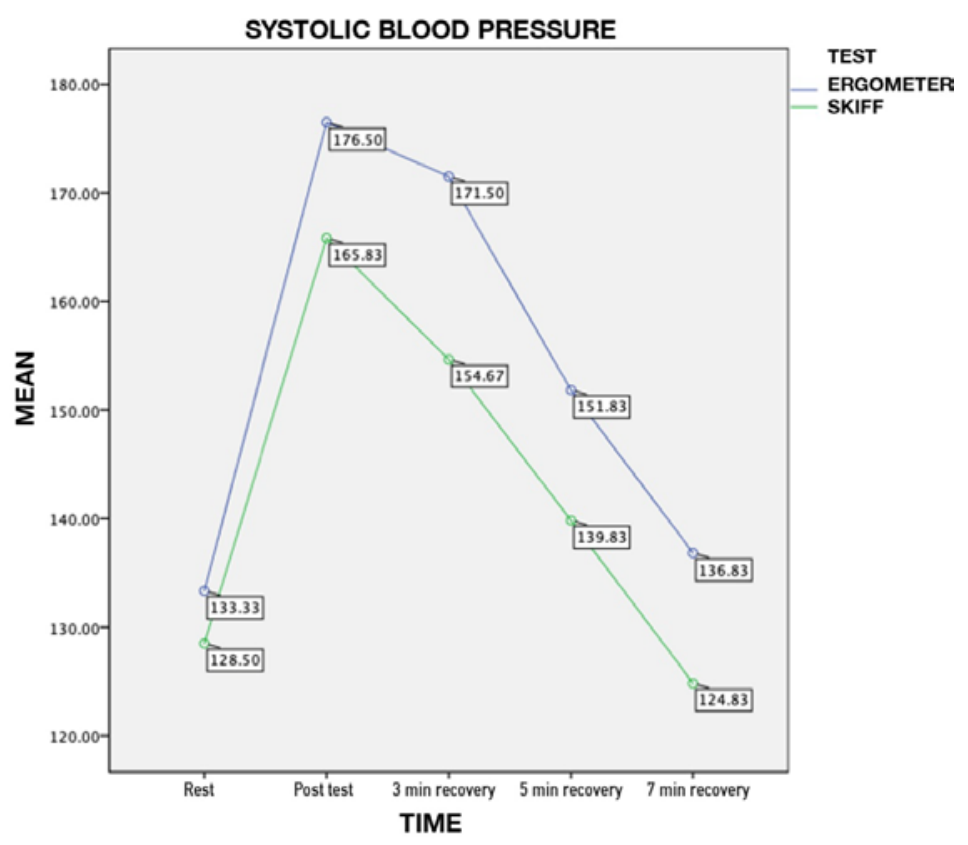

Figure 4. Diagram of systolic pressure versus time and test

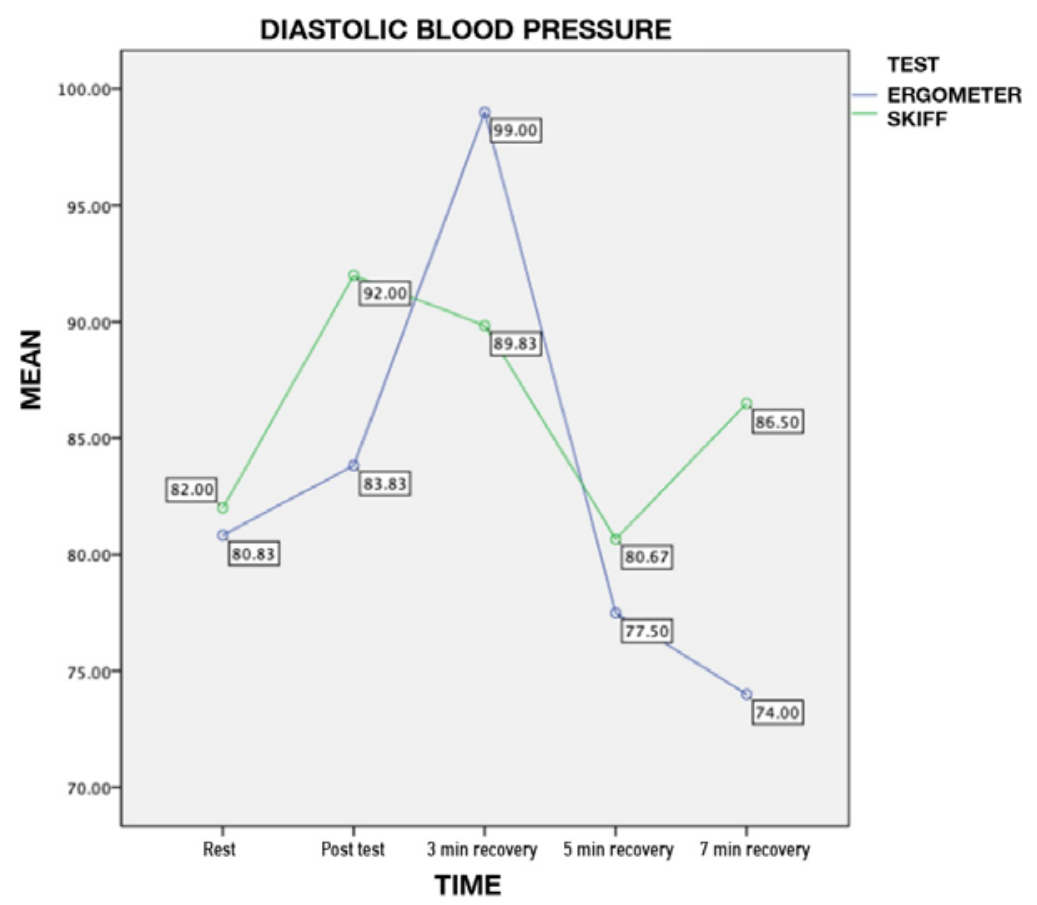

Figure 5. Diastolic pressure diagrams according to time and test 


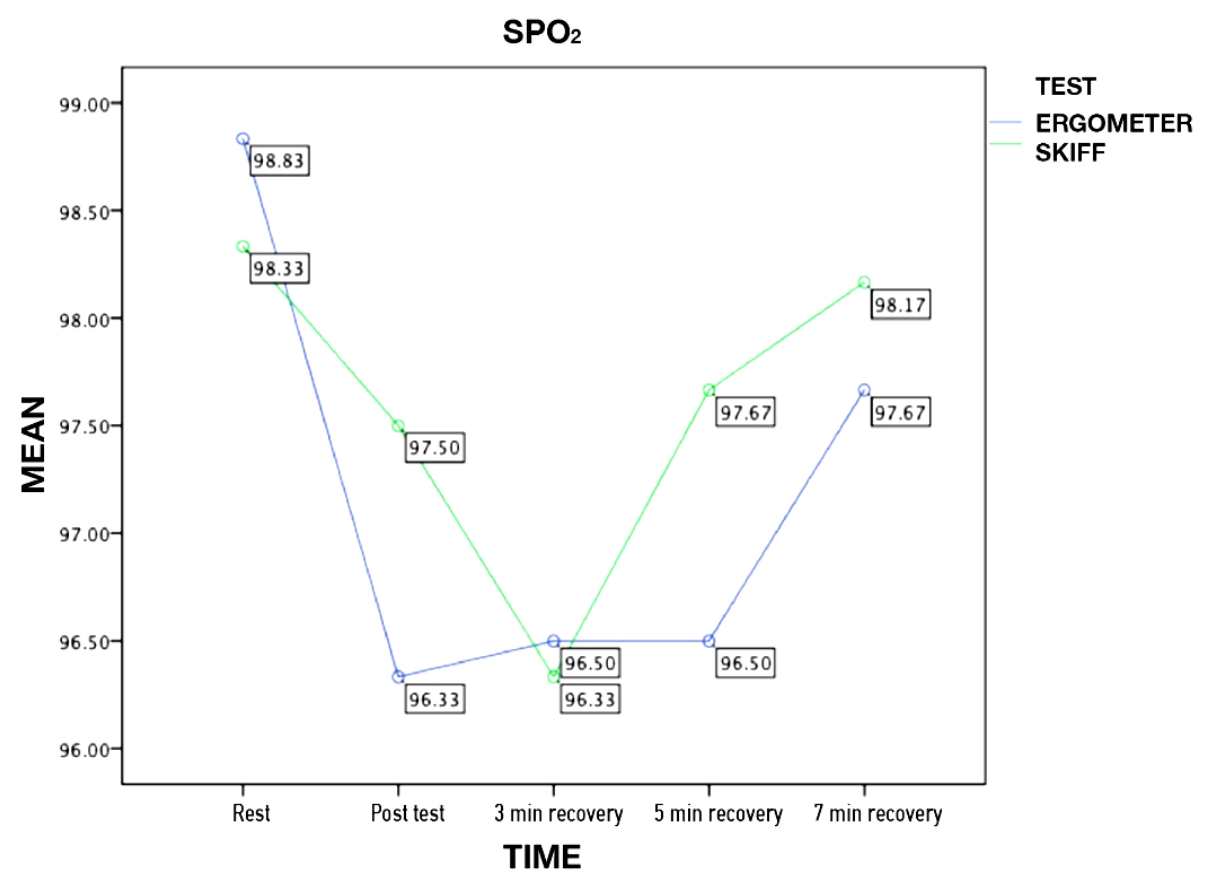

Figure 6. Diagram of SPO2 depending on the time and ergometer

\section{DISCUSSION}

This study compared the acute cardiovascular responses of the six rowing athletes during performance tests in laboratory and in field conditions.

The heart rate and oxygen saturation values measured in laboratory and on water did not show statistically significant differences between the two tests. These findings coincide with the results of the previous studies, which also did not detect differences in heart rate values at the anaerobic thresholds between these two types of rowing tests $(14-16)$. However, one previous study had recorded higher heart rate values in the laboratory assessment compared to the field-based test and indicated that this may be due to the relatively larger body mass movement during rowing in the laboratory, compared to rowing in the water (17). However, this research was conducted more than 30 years ago where another rowing ergometer rather than the modern Concept 2 was used, a factor that might have a significant impact on the interpretation of the findings.

Acute cardiovascular responses to exercise constitute for the short-term responses of the circulatory system (heart rate, pulse volume, etc.) that last only during and short after the exercise (18, 19). Only few studies to date compared acute cardiovascular responses in rowing athletes between labo- ratory and field-based tests $(12,14)$. In a survey of 21 rowers by Rosiello et al., it was found that at similar levels of oxygen consumption and heart rate showed significantly higher values (while the pulse volume was significantly lower) during rowing in water compared to the executed exercise on the ergometer (20). In another survey of 9 high-level rowers, it was found that the rise in heart rate variability on the Concept 2 rowing test was associated with increased exercise intensity, possibly indicating a positive adaptation to training (21). Although it is generally reported that the heart rate is higher in water, Fleming et al. found that ergometer performance in the laboratory may be associated with a higher heart rate compared to the field evaluation (22). On the other hand, a more recent study, similarly to our study results, concluded that statistically significant differences in heart rate values were not evident between field and laboratory tests (14).

Blood pressure values recorded in this study during both trials, in the laboratory and in the water, varied statistically significant over the range of changes of the exercise, but the mutual differences were not significant. However, this was not the case with diastolic pressure values. They were significantly different between two types of tests in the measurements taken immediately after the completion of the rowing test and at the end of the $7^{\text {th }}$ minute of recovery. Interestingly, a previously con- 
ducted study that compered rowing and cycling cardiovascular responses did not found statistically significant differences between blood pressure values assessed after the two submaximal tests (19). Differences detected in diastolic pressure values between the two rowing tests can be attributed to the possible changes in the blood and pulse volume or to presumable different hemodynamic changes that occur during exercise on the rowing ergometer versus exercise on the boat (20). The training level may have also affected the diastolic pressure changes as previous research had shown that highly trained rowers have larger volumes of the left ventricle, significantly enhanced left ventricular systolic function and pronouncedly dilated left and right ventricular cavities compared to sub-elite rowers (24). However, dynamics of the changes between the different values of the diastolic pressure in the two rowing tests require more research.
The small size of the sample limits the generalization of the gathered results and it is therefore suggested that the future research should be conducted on larger samples of rowing athletes and preferably classified in weight categories (25). Overall, a comparison of the cardiovascular responses of athletes tested in the laboratory and in the field conditions showed that there were only minor fluctuations in the cardiovascular responses of the rowing athletes, indicating that the laboratory test was quite reliable compared to actual rowing in the water.

\section{Acknowledgment}

None.

\section{Conflicts of Interest}

The authors declare no conflict of interest.

\section{References}

1. Smith TB, Hopkins WG. Measures of rowing performance, Sports Med. 2012; 42, 343-58. https://doi.org/10.2165/11597230-000000000-00000

2. Mäestu J, Jürimäe J, Jürimäe T. Monitoring of performance and training in rowing. Sports Med. 2005; 35(7):597-617.

https://doi.org/10.2165/00007256-200535070-00005

3. Egan-Shuttler JD, Edmonds R, Eddy C, et al. Beyond Peak, a Simple Approach to Assess Rowing Power and the Impact of Training: A Technical Report. Int J Exerc Sci. 2019;12(6):233-44. eCollection.

4. Mendel RW, Cheatham CC. Laboratory and Field Techniques for Measuring Performance. In: Antonio J, Kalman D, Stout JR, Greenwood M., Willoughby DS, Haff GG, editors. Essentials of Sports Nutrition and Supplements. Urdorf:
Humana Press; 2008. p. 159-182.

5. Karsten, B, Jobson, S, Hopker J, et al. High agreement between laboratory and field estimates of critical power in cycling. Int. J. Sports Med. 2013; 5, 298-303.

https://doi.org/10.1055/s-0033-1349844

6. Mello FC, de Moraes Bertuzzi RC, Grangeiro PM, et al. Energy systems contributions in 2,000 $\mathrm{m}$ race simulation: a comparison among rowing ergometers and water. Eur J Appl Physiol 2009; 107(5):615-19 https://doi.org/10.1007/s00421-009-1172-9

7. Lamb DH. A kinematic comparison of ergometer and on-water rowing. Am J Sports Med. 1989; 17(3):367-73. https://doi.org/10.1177/036354658901700310 
8. Martindale W, Robertson D. Mechanical energy in sculling and in rowing an ergometer. Can J Appl Sport Sci. 1984; 9(3):153-63.

9. Dawson R, Lockwood R, Wilson J, et al. The rowing cycle: sources of variance and invariance in ergometer and on-the-water performance. J Mot Behav 1998; 30(1):33-43. https://doi.org/10.1080/00222899809601320

10. Elliott B, Lyttle A, Birkett O. The RowPerfect ergometer: a training aid for on-water single scull rowing. Sports Biomech. 2002; 1(2):123-34. https://doi.org/10.1080/14763140208522791

11. Steinacker J, Michalsky R, Grünert-Fuchs M, et al. Field tests in rowing (English translation of Feldtests im rudern). Dtsch Z Sportmed 1987; 38:19-26

12. Coen B, Urhausen A, Kindermann W. Sport specific performance diagnosis in rowing: an incremental graded exercise test in coxless pairs. Int J Sports Med. 2003; 24(6):428-32. https://doi.org/10.1055/s-2003-41178

13. Bazzucchi I, Sbriccoli P, Nicolò A, et al. Cardiorespiratory and electromyographic responses to ergometer and on-water rowing in elite rowers. Eur J Appl Physiol 2013; 113(5):1271-7. https://doi.org/10.1007/s00421-012-2550-2

14. Kleshnev V. Comparison of on-water rowing with its simulation on Concept2 and Row perfect machines (abstract). In ISBS-Conference Proceeding Archive 2008, 1, No. 1.

15. Vogler AJ, Rice A J, Gore CJ. Physiological responses to ergometer and on-water incremental rowing tests. IJSPP 2010; 5, 342-58.

https://doi.org/10.1123/ijspp.5.3.342

16. Urhausen A, Weiler B, Kindermann W. Heart rate, blood lactate, and catecholamines during ergometer and on water rowing. Int. J. Sports Med. 1993; 14, S20-3.

https://doi.org/10.1055/s-2007-1021218
17. Steinacker J, Michalsky R, Grünert-Fuchs M, et al. Field tests in rowing (English translation of Feldtestsimrudern). Dtsch Z Sportmed 1987; 38, 19-26.

18. Navare SM, Thompson PD. Acute cardiovascular response to exercise and its implications for exercise testing. J Nucl Cardiol 2003; 10(5):521-8. https://doi.org/10.1016/S1071-3581(03)00626-3

19. Gleim GW, Coplan NL, Nicholas JA. Acute cardiovascular response to exercise. Bull $\mathrm{N} \mathrm{Y}$ Acad Med. 1986; 62(3): 211-8.

20. Rosiello RA, Mahler DA, Ward JL. Cardiovascular responses to rowing. Med Sci Sports Exerc 1987; 19, 239-45.

https://doi.org/10.1249/00005768-198706000-00010

21. Plews DJ, Laursen PB, Kilding AE, et al. Heartrate variability and training-intensity distribution in elite rowers. Int J Sports Physiol Perform 2014; 9, 1026-32. https://doi.org/10.1123/ijspp.2013-0497

22. Fleming N, Donne B, Mahony NA. Comparison of electromyography and stroke kinematics during ergometer and on-water rowing. J. Sports Sci. 2014; 32, 1127-38.

https://doi.org/10.1080/02640414.2014.886128

23. Horn P, Ostadal P, Ostadal B. Rowing increases stroke volume and cardiac output to a greater extent than cycling, Physiol. Res. 2015; 64, 203-7. https://doi.org/10.33549/physiolres.932853

24. Baggish AL, Yared $\mathrm{K}$, Weiner RB, et al. Differences in cardiac parameters among elite rowers and subelite rowers (No. M09-51). Army Research Inst of Environmental Medicine Natick Ma Thermal and Mountain Medicine Division, 2010.

https://doi.org/10.1249/MSS.0b013e3181c81604

25. Nevill AM, Beech C, Holder RL, et al. Scaling concept II rowing ergometer performance for differences in body mass to better reflect rowing in water. Scand J Med Sci Sports 2010; 20, 122-7. https://doi.org/10.1111/j.1600-0838.2008.00874.x 


\title{
Upoređivanje akutnih kardiovaskularnih odgovora veslača tokom testa opterećenja u laboratorijskim uslovima i na vodi
}

\author{
Nikolaos Koutlianos, Nikolaos Panolias, Milena Tomović, Serafeim Alexiou \\ Laboratorija za sportsku medicine, Fakultet za fizičku kulturu i sport, Aristotelov univerzitet u Solunu, \\ Solun, Grčka
}

S A ŽETAK

Ova studija poredi akutne kardiovaskularne odgovore veslača tokom testa opterećenja u laboratorijskim uslovima i na vodi sa ciljem da identifikuje moguće razlike između ta dva tipa testiranja.

Šest veslača je testirano na Concept2 veslačkom ergometru u laboratoriji i u skifu na vodi. Tokom oba testa mereni su srčana frekvenca, krvni pritisak (sistolni i dijastolni) i saturacija kiseonika u krvi (\% SpO2).

Analiza dobijenih podataka nije pokazala statistički značajnu razliku između laboratorijskog $i$ testa na vodi kada je u pitanju srčana frekvenca $(p>0.05)$, sistolni krvni pritisak $(p>0.05)$ i saturacija kiseonika $u$ krvi ( $p>0.05$ ), isti parametri su tokom oba testa imali sličan trend rasta odnosno opadanja. Jedino se vrednost dijastolnog krvnog pritiska registrovana neposredno nakon testa i tokom sedmominutnog oporavka statistički značajno razlikovala između ova dva tipa testiranja.

Kardiovaskulari odgovori veslača registrovani tokom testa u laboratoriji i na terenu (u vodi) nisu pokazali velika odstupanja $i$ iz toga možemo zaključiti da se podaci dobijeni testiranjem veslača u laboratorijskim uslovima mogu koristiti kao pouzdani za procenu utreniranosti i planiranje trenažnog procesa veslača. Ipak, smatra se da terenska testiranja nude veću pouzdanost i specifičnost jer bolje imitiraju stvarne takmičarske uslove.

Ključne reči: veslanje, ergometrija, testovi na terenu, kardiovaskularni odgovor na vežbanje 